\title{
Indices of zooplankton community as valuable tools in assessing the trophic state and water quality of eutrophic lakes: long term study of Lake Võrtsjärv
}

\author{
Juta HABERMAN, Marina HALDNA* \\ Centre for Limnology, Estonian University of Life Sciences, 61117 Rannu, Tartumaa, Estonia \\ *Corresponding author: marina.haldna@emu.ee
}

\begin{abstract}
On the basis of long-term (1964-2011) research, we tested the hypothesis that the zooplankton community has a highly indicative value in assessing the ecosystem and trophic state of water bodies. Basing on the results of our study and taking into account relevant data from numerous zooplankton studies, we can conclude that the zooplankton measures deserving to be used as indicators in the monitoring of Lake Vortsjärv (and other similar eutrophic water bodies) could be the following: i) indicatory species of eutrophic waters [Anuraeopsis fissa (Gosse), Keratella tecta (Gosse), Trichocerca rousseleti (Voigt), Chydorus sphaericus (O.F. Müller), Bosmina longirostris (O.F. Müller)]; ii) indicatory species of oligo-mesotrophic waters [Conochilus unicornis Rousselet, Kellicottia longispina (Kellicott), Ploesoma hudsoni (Imhof), Bosmina berolinensis Imhof, Eudiaptomus gracilis (Sars)]; iii) number and diversity of species; iv) mean zooplankter weight, mean cladoceran weight, mean rotifer weight and mean copepod weight; v) rotifer abundance; vi) the share $(\%)$ of rotifers in total zooplankton abundance; vii) the ratio of abundance of large cladocerans to abundance of all cladocerans $\left(N_{\text {Large- }}\right.$ $\left.{ }_{\text {Clad }} / N_{\text {Clad }}\right)$; viii) the ratio of calanoid copepod abundance to cyclopoid copepod abundance $\left(N_{\text {Cal }} / N_{\text {Cycl }}\right)$; ix) the ratio of crustacean abundance to rotifer abundance $\left(N_{\text {Crust }} / N_{\text {Rot }}\right)$. The results of our study show that several zooplankton parameters are among the biological quality elements $(B Q E)$ deserving to be included in the Water Frame Directive system.
\end{abstract}

Key words: zooplankton, biological indicators, eutrophication, ecological state of lake.

Received: August 2013. Accepted: December 2013.

\section{INTRODUCTION}

Recent decades have seen an increasing demand for effective monitoring methods based on biotic indices (Duggan et al., 2001; Haberman and Laugaste, 2003; Carpenter et al., 2006; Kane et al., 2009; Blank et al., 2010; Jeppesen et al., 2011; Del Arco et al., 2012; EjsmontKarabin, 2012). With the implementation of the European Union Water Framework Directive, the member states have to classify the ecological status of surface waters on the basis of a series of biological quality elements (BQE; phytoplankton, macrophytes, phytobenthos, macroinvertebrates, fish). As a matter of surprise to many ecologists (Moss, 2007; Caroni and Irvine, 2010; Davidson et al., 2011; Jeppesen et al., 2011, Ejsmont-Karabin, 2012), zooplankton was not included as a $\mathrm{BQE}$ despite the fact that it is considered a key component of pelagic food webs.

Several earlier studies conducted on Lake Võrtsjärv have shown the high indicative ability of zooplankton to reflect the state of the ecosystem and water quality. The first data of the zooplankton of Lake Võrtsjärv were presented in the monograph of M. Mühlen and G. Schneider (1920), where the lake was classified as a eutrophic water body dominated by Chydorus sphaericus. Grazing rate of herbivorous zooplankton is one of the indicators of the trophic state of a lake, which decreases in parallel with increasing trophic level (Gulati, 1984; 1990; Ivanova, 1985; Jeppesen et al., 1999; Nõges et al., 2004; Agasild et al., 2007). Agasild et al. (2007) measured the grazing impact of zooplankton on phytoplankton biomass in Lake Võrtsjärv. The average daily filtering and grazing rate of the whole zooplankton community remained low, only $4 \%$ of the total phytoplankton biomass. Also the cladoceran community has proved to be an informative indicator of the trophic state of water bodies and of the efficiency of the food web (Davidson et al., 2011). The role of cladocerans in reflecting the trophic state was addressed on the basis of a comparative study (1997-2003) conducted in the strongly eutrophic Lake Võrtsjärv (TP $54 \mu \mathrm{g} \mathrm{L}^{-1}$, TN $\left.1600 \mu \mathrm{g} \mathrm{L}^{-1}\right)$ and in the moderately eutrophic Lake Peipsi (TP $35 \mu \mathrm{g} \mathrm{L}^{-1}$, TN $678 \mu \mathrm{g} \mathrm{L}^{-1}$ ) (Haberman et al., 2007). In Lake Peipsi, characteristic species of oligomesotrophic and eutrophic waters co-existed, whereas in Lake Võrtsjärv only species of eutrophic waters occurred. Cladoceran individuals were three times smaller in Lake Vorrtsjärv than in Lake Peipsi; the abundance of Chydorus sphaericus (O. F. Müller) was almost four times higher in Lake Võrtsjärv than in Lake Peipsi, and the abundance of cladocerans was almost two times higher in Lake Võrtsjärv while their biomass was only less than half of the corresponding parameter for Lake 
Peipsi. The zooplankton to phytoplankton biomass ratio $\left(\mathrm{B}_{\mathrm{Zp}} / \mathrm{B}_{\text {Phyt }}\right)$ reflects adequately the trophic state of a water body and decreases with increasing trophy (Gulati, 1984; Andronikova, 1996; Jeppesen et al., 1999, 2000, 2011; Blank et al., 2010). In the highly eutrophic Lake Võrtsjärv, $\mathrm{B}_{\mathrm{Zp}} / \mathrm{B}_{\text {Phyt }}$ ranges from 0.04 to 0.22 during the growing season with an average of 0.13 (Haberman, 1998; Haberman and Laugaste, 2003). The low average $\mathrm{B}_{\mathrm{Zp}} / \mathrm{B}_{\text {Phyt }}$ indicates the high trophic level of Lake Võrtsjärv. Blank et al. (2010) and Jeppesen et al. (2011) have found that the mean value of $\mathrm{B}_{\mathrm{Zp}} / \mathrm{B}_{\text {Phyt }}$ in the growing season is a reliable indicator for assessing the quality of the ecosystem and the water of a lake. The ratio of production of plankton filtrators to primary production (PFilt/PP), is an evidence of the food web type, either effective grazing or ineffective detrital (microbial). The type of the food web in a water ecosystem is considered a high indicator of the state of the ecosystem and water quality; it can be a hundred times more effective in oligotrophic than in hypertrophic waters (Ivanova, 1985; Downing et al., 1990). In the strongly eutrophic Vorrtsjärv, from where efficient filtrators have disappeared, the ratio PFilt/PP was 0.02-0.03 (Haberman, 1998; Nõges et al., 1998). It means that only about $2 \%$ of primary production reaches zooplankton, and the lake is dominated by the ineffective detrital food web.

The aim of present study was: i) to test, on the basis of long term (47-year) research, the hypothesis that the zooplankton community has a highly indicative value in assessing the ecosystem and trophic state of water bodies; ii) to determine which zooplankton characteristics could serve as indicators facilitating the future monitoring of zooplankton in Lake Võrtsjärv.

\section{METHODS}

\section{Study site}

Lake Võrtsjärv, situated in Central Estonia, is the second largest $\left(270 \mathrm{~km}^{2}\right)$ lake in the Baltic countries, characterized by small depth (mean $2.8 \mathrm{~m}$, maximum $6 \mathrm{~m}$ ) and high trophy (during 1983-2011 average total phosphorus $50 \mu \mathrm{g} \mathrm{L}^{-1}$, total nitrogen $1500 \mu \mathrm{g} \mathrm{L}^{-1}$ ). The shallowness of the lake and the resuspension of bottom sediments by the waves contribute to the high seston content of the water; mean transparency of the water usually does not exceed $1 \mathrm{~m}$ during the ice-free period. The ice cover lasts from mid-November to mid-April, 135 days as an average. Mean water temperature reaches its maximum $\left(19.8^{\circ} \mathrm{C}\right)$ in July. The lake belongs to the polymictic type. Owing to high alkalinity (average $\mathrm{pH} 8.4$ during the ice-free period), the water of the lake is well buffered. The water residence time is about one year. The phytoplankton of Lake Võrtsjärv is mainly dominated by the cyanobacteria Limnothrix planktonica (Wołosz.) Meffert and Limnothrix re- dekei (van Goor) Meffert, which are accompanied by Planktolyngbya limnetica (Lemm.) Kom.-Legn. and Aphanizomenon skujae Kom.-Legn. and Cronb. Mean phytoplankton wet biomass in the ice-free period is $20 \pm 14 \mathrm{mg}$ $\mathrm{L}^{-1}$ (Nõges et al., 2007) and mean annual chlorophyll concentration $27 \mu \mathrm{g} \mathrm{L}^{-1}$ (Nõges et al., 2008). The total number of bacteria amounts to $6 \cdot 10^{6}$ cells $\mathrm{mL}^{-1}$ (Kisand and Nõges, 1998). In the 1950s the planktivorous fishes vendace (Coregonus albula (L.) and lake smelt (Osmerus eperlanus eperlanus m.spirinchus Pallas), characteristic of low trophy, were numerous; at present, their numbers have greatly declined due to the eutrophication of the lake. The eutrophication process started in the 1970s, peaked in the 1980s-1990s and stagnated in the 2000s.

\section{Sampling and analysis}

Quantitative samples were collected monthly from the pelagial of the lake between the Centre for Limnology and Tondisaar Island $\left(58^{\circ} 12^{\prime} 20^{\prime \prime} \mathrm{N}\right.$; $\left.26^{\circ} 05^{\prime} 09^{\prime \prime} \mathrm{E}\right)$. Main trends in the zooplankton and hydrochemical variables in the shallow eutrophic Lake Võrtsjärv were discussed on the basis of 47-year (1964-2011) data for the growing season. The water transparency (SD), concentrations of total phosphorus (TP), total nitrogen (TN), nitrates $\left(\mathrm{NO}_{3}\right)$, phosphates $\left(\mathrm{PO}_{4}\right)$ were analysed to measure the trophic state of Lake Võrtsjärv and changes in it during 19642011. The concentrations of $\mathrm{NO}_{3}, \mathrm{PO}_{4}$ and Secchi disc were analysed from 1964 to 2011, and the concentrations of TP and TN were analysed from 1983 to 2011. In the earlier period (1964-2000), zooplankton samples were taken with a quantitative Juday net of $85 \mu \mathrm{m}$ mesh from bottom to surface. From 2000, a series of one-litre samples were taken with a Ruttner sampler at one-metre intervals from surface to bottom and mixed in a sample tank. For a zooplankton sample, $20 \mathrm{~L}$ of mixed water were filtered through a net of $48 \mu \mathrm{m}$ mesh. It is generally accepted that plankton nets do not retain the smallest rotifers efficiently. To render rotifer abundance applicable, correction coefficients (Virro, 1989), developed on the basis of comparing net and bathometer samples, were used. Zooplankton samples were fixed with acidified Lugol's solution, counted under a binocular microscope in the Bogorov chamber and enumerated at $56 \times$ magnification. For biomass calculations, the average body length of 20 individuals (if possible) from each taxon was measured. Individual rotifer weights were estimated from average lengths according to Ruttner-Kolisko (1977). The lengths of crustaceans were converted to weights according to Studenikina and Cherepahina (1969, nauplii), Balushkina and Vinberg (1979, other groups).

The annual data for $\mathrm{P}$ and $\mathrm{N}$ loadings were available from Nõges et al. (2010). A shift detection calculator (Rodionov, 2004) was used to detect significant increases and decreases in $\mathrm{P}$ and $\mathrm{N}$ loadings as well as in lake water con- 
centration trends for the study period. Indicator species analysis was conducted on the basis of species abundances for different decades (1960s-2000s) as different environmental conditions. Group-equalized IndVal.g was used as the association index. For assessing bioversity on the basis of zooplankton, Shannon-Wiener's index was used. The trophic state indices of rotifer abundance (Ejsmont-Karabin, 2012) were calculated to illustrate the usefulness of rotifer abundance and mean rotifer weight $(\overline{\mathrm{W}})$ as indicators of lake trophy (Tab. 1). Also various ratios were analysed: (1) mean zooplankton weight as well as mean cladoceran weight, mean copepod weight and mean rotifer weight; (2) the ratio of crustacean abundance to rotifer abundance $\left(\mathrm{N}_{\text {Crust }} / \mathrm{N}_{\text {Rot }}\right)$; (3) the ratio of calanoid copepod abundance to cyclopoid copepod abundance $\left(\mathrm{N}_{\text {Cal }} / \mathrm{N}_{\text {Cycl }}\right)$; (4) the ratio of large (>10 $\left.\mu \mathrm{g}\right)$ cladoceran abundance to total cladoceran group abundance $\left(\mathrm{N}_{\text {Large- }}\right.$ Clad $\left(\mathrm{N}_{\text {Clad }}\right.$ ). To evaluate differences in the studied nutrients (log-transformed data) between the decades and the indices of the trophic state, analysis of variance, followed by the Tukey HDS multiple comparison test, was employed. As the distribution of zooplankton abundances was not obtained, then in order to compare these metrics for the studied decades, the non-parametric Kruskal-Wallis test, followed by Dunn's multiple comparisons, was used. All calculations were carried out using the $\mathrm{R}$ vegan and indispecies packages (Oksanen et al., 2011; R Development Core Team, 2011).

\section{RESULTS}

A regime shift detection calculator identified an increase in the TN loading for $1982(\mathrm{P}=0.0001)$ and a decrease for $1991(\mathrm{P}<0.0001)$. For the TP loading as well as for TP concentration, a decrease was observed for 1994$1995(\mathrm{P}=0.0003)$. A significant declining shift in the variability of TP concentration was identified for 2001 $(\mathrm{P}=0.028)$. Considering these essential shifts in the trophic state of the lake, we divided the study period into distinct decades (from the 1960 s to the 2000 s).

The mean values of nutrients (TN, TP, $\left.\mathrm{NO}_{3}, \mathrm{PO}_{4}\right)$ and water transparency for different decades demonstrate changes in the water of Lake Võrtsjärv during long-term study (Tab. 2). Nutrient dynamics in the lake followed changes in the loading, indicating the ability of the

Tab. 1. Formulas used for the calculation of the studied indices.

\begin{tabular}{lcc}
\hline Index & Formula & Reference \\
\hline IndVal.g & $\frac{a_{p} / N_{p}}{\sum_{k=1}^{K} a_{k} / N_{k}} \times \frac{n_{p}}{N_{p}}$ & De Cáceres and Legendre (2009) \\
TSI $_{\mathrm{NRot}}$ & $5.38 \times \ln \left(N_{R o t}\right)+19.28$ & Ejsmont-Karabin (2012) \\
TSI $_{\text {Rot } \overline{\mathrm{W}}}$ & $3.8 \overline{5} \times(\operatorname{Rot} \overline{\mathrm{W}})^{-0.318}$ & Ejsmont-Karabin (2012) \\
TSI $_{\mathrm{SD}}$ & $60-14.41 \times \ln (S D)$ & Carlson (1977) \\
TSI $_{\mathrm{TP}}$ & $14.42 \times \ln (T P)+4.15$ & Carlson (1977) \\
Shannon's diversity & $-\sum p_{i} \ln \left(p_{i}\right)$ & Shannon (1948)
\end{tabular}

$\mathrm{a}_{\mathrm{p}}$, sum of the abundance values of the species of the observation; $\mathrm{N}_{\mathrm{p}}$, number of observations belonging to the target decade; $\mathrm{n}_{\mathrm{p}}$, number of occurrences of the species within the target decade; $K$, the number of decades; $\mathrm{N}_{\mathrm{k}}$, number of observations belonging to the $\mathrm{k}$ th decade; $\mathrm{a}_{\mathrm{k}}$, sum of the abundance values of the species in the $\mathrm{k}$ th decade; $\mathrm{N}_{\mathrm{Ro}}$,rotifer abundance; Rot $\bar{W}$, mean weight of rotifer individuals, SD-water transparency, TP, total phosphorus concentration $(\mu \mathrm{g} / L) ; \mathrm{p}_{\mathrm{i}}$, proportion of the species i relative to the total number of species.

Tab. 2. Mean values ( \pm standard error) of nutrients and water transparency, P-values of multiple comparison test (Tukey HSD) for the studied decades. Underlined values indicate significantly distinctive decades.

\begin{tabular}{|c|c|c|c|c|c|c|}
\hline Variable & $1960 \mathrm{~s}$ & $1970 \mathrm{~s}$ & $1980 \mathrm{~s}$ & $1990 \mathrm{~s}$ & $2000 \mathrm{~s}$ & P-value \\
\hline \multicolumn{3}{|c|}{ Total nitrogen, $\mu \mathrm{g} \mathrm{L}^{-1}$} & $\underline{1420 \pm 90}$ & $1380 \pm 45$ & $1310 \pm 35$ & 0.017 \\
\hline \multicolumn{3}{|c|}{ Total phosphorus, $\mu \mathrm{g} \mathrm{L}^{-1}$} & $53 \pm 3.4$ & $51 \pm 2.2$ & $43 \pm 1.2$ & NS \\
\hline Nitrate, $\mu \mathrm{gP} \mathrm{L}^{-1}$ & $260 \pm 40$ & $\underline{580 \pm 70}$ & $754 \pm 150$ & $440 \pm 40$ & $560 \pm 54$ & 0.041 \\
\hline Phosphate, $\mu g \mathrm{PL} \mathrm{L}^{-1}$ & $9 \pm 2.5$ & $10 \pm 3.5$ & $\underline{26 \pm 6.2}$ & $14 \pm 1.2$ & $13 \pm 0.7$ & 0.002 \\
\hline Secchi disc, $\mathrm{m}$ & $1.1 \pm 0.08$ & $1.1 \pm 0.05$ & $\overline{1.0 \pm 0.03}$ & $1.0 \pm 0.02$ & $0.9 \pm 0.02$ & NS \\
\hline
\end{tabular}

NS, not significant. 
ecosystem of this shallow lake to respond sensitively to changes in the management of the catchment basin, while the content of nutrients still remained at a quite high level, with only a slight decline in the 2000s. Analysis of variance revealed a higher mean value for $\mathrm{TN}$ and $\mathrm{PO}_{4}$ in 1980s compared to the other decades and significant rise of $\mathrm{NO}_{3}$ concentration in 1970s (Tab. 2). According to Vollenweider and Kerekes (1982), the lake is hypertrophic with a TP water concentration of $\geq 80 \mu \mathrm{g} \mathrm{L}^{-1}$. In the $1980 \mathrm{~s}$ and 1990s, TP concentration in the water of the lake frequently exceeded $80 \mu \mathrm{g} \mathrm{L}^{-1}$. The highest phosphate and total phosphorus concentrations were measured in March of $1986\left(185 \mu \mathrm{g} \mathrm{L}^{-1}\right.$ and $250 \mu \mathrm{g} \mathrm{L}^{-1}$, respectively). Carlson's indices $\mathrm{TSI}_{\mathrm{TP}}\left(\right.$ mean $60 \pm 2$ ) and $\mathrm{TSI}_{\mathrm{SD}}(65 \pm 3$ ), allow classify Lake Võrtsjärv as a eutrophic water body in all decades. Also Ejsmont-Karabin's (2012) trophic state indices for rotifer abundance (TSI $\mathrm{NRot}_{\text {t) }}$ and for rotifer mean weight $\left(\mathrm{TSI}_{\text {Rot } \mathrm{W}}\right)$ characterized Lake Võrtsjärv as a eu-

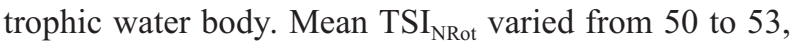
and mean TSI $I_{\text {Rot } \bar{V}}$ varied from 53 in the 1960s to 65 in the 1980s. The zooplankton of Lake Võrtsjärv, monitored regularly since 1964, has undergone major changes.

A study conducted during the growing season (MayOct) identified 54 metazooplankton species in the pelagial of Lake Võrtsjärv: 29 rotifers, 17 cladocerans, and 8 copepods. The number of species decreased significantly during 1964-2011 $(\mathrm{P}<0.001$, Fig. 1). The Shannon-Wiener diversity analysis revealed a substantial decrease in species diversity for all zooplankton groups (Fig. 2). The mean abundance (ind $\mathrm{L}^{-1}$ ) of total zooplankton, zooplankton groups (Cladocera, Copepoda, Rotifera) and key species of the present study showed several changes in the zooplankton community during the five decades (Tab. 3). Zooplankton abundance in the eutrophic Lake Võrtsjärv was mainly built by rotifers ( $65 \%$ ), followed by cladocerans $(20 \%)$ and copepods (15\%) (Fig. 3). The zooplankton community was dominated by only a few (1-2) species, which is characteristic of strongly eutrophic lakes. Rotifers were dominated more frequently by Polyarthra luminosa Kutikova and Keratella cochlearis (Gosse), cladocerans were mainly dominated by Chydorus sphaericus, and copepods were dominated by juvenile forms of the genus Mesocyclops. From the 1980s, the zooplankton community was dominated also by the abundant small rotifer Anuraeopsis fissa (Gosse) (Tab. 3).

During the study period essential changes took place in the indicatory species of zooplankton (Tab. 4). A characteristic feature of Lake Võrtsjärv is the disappearance of indicator species of meso-oligotrophic waters and the dominance of indicators of eutrophy alone. The species characteristic of lower trophy were Conochilus unicornis Rousselet, Kellicottia longispina (Kellicott), Ploesoma hudsoni (Imhof), Cyclops kolensis Lilljeborg, Eudiaptomus gracilis (Sars); the species characteristic of eutrophy were

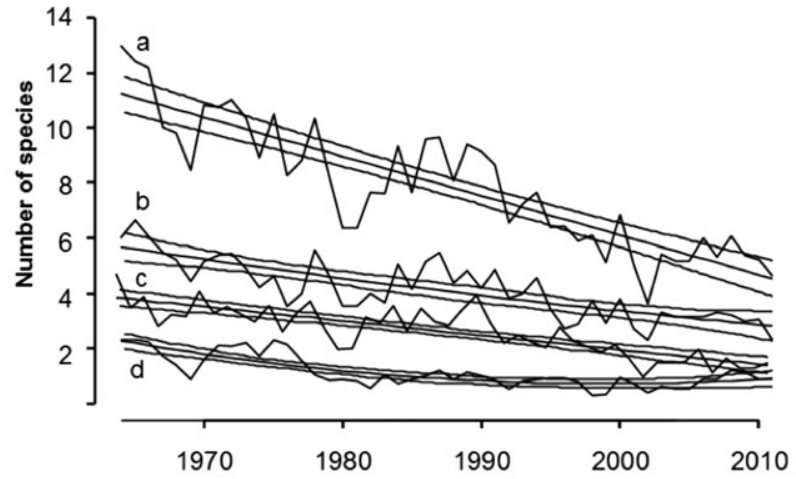

Fig. 1. Mean number of species with a trend and $95 \%$ confidence limits. a, total zooplankton; b, Rotifera; c, Cladocera; d, Copepoda.

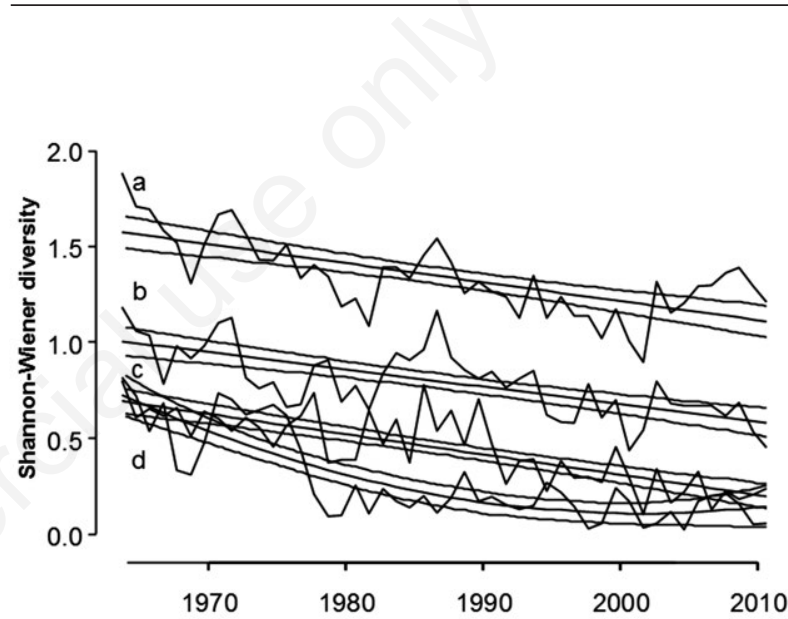

Fig. 2. Mean values of the Shannon-Wiener diversity indice with a trend and 95\% confidence limits. a, total zooplankton; b, Rotifera; c, Cladocera; d, Copepoda.

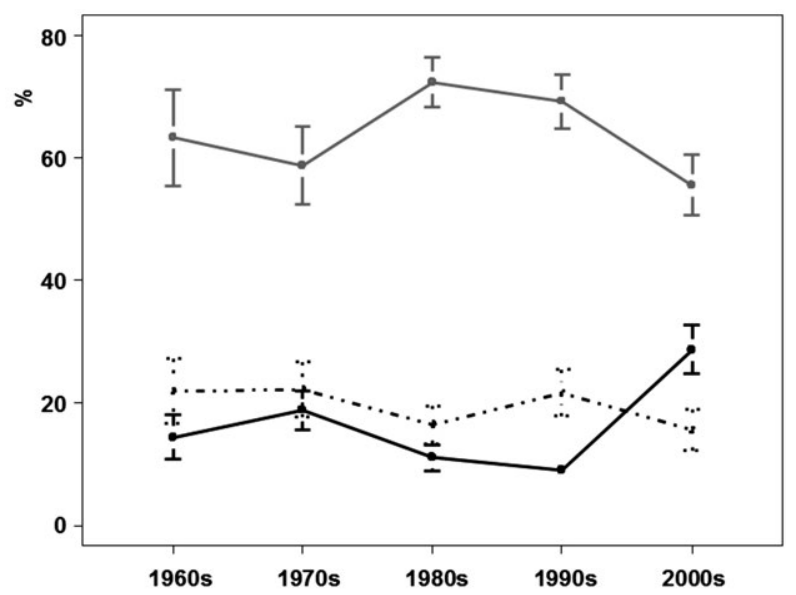

Fig. 3. Share in percentage of zooplankton groups (dotted line, Cladocera; black line, Copepoda; grey line, Rotifera) in total zooplankton abundance for the growing season (mean of the decade with the $95 \%$ confidence limits). 
A. fissa, Trichocerca rousseleti (Voigt) and, to a less extent, species of the genus Mesocyclops. In Lake Võrtsjärv, zoo-

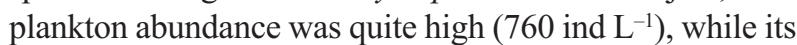
biomass was low $\left(1.1 \mathrm{mg} \mathrm{L}^{-1}\right)$, which is characteristic of highly eutrophic water bodies with a small weight of zooplankton individuals. In Lake Võrtsjärv mean zooplankter weight $(2.7 \pm 0.2 \mu \mathrm{g})$ and the mean weights of individuals in different zooplankton groups were small (rotifer, $0.7 \mu \mathrm{g}$; cladoceran, $9 \mu \mathrm{g}$; copepod, $6 \mu \mathrm{g}$ ), which characterizes a highly eutrophic water body. Mean zooplankter weight was the smallest in the 1980s $(2 \mu \mathrm{g})$ with the highest trophic state of the lake (Fig. 4), which was obviously caused by a significant rise in the abundance of the small A. fissa
(Fig. 5) as well as by T.rousseleti (Tab. 3). Also the mean weights of individuals in the different zooplankton groups were the smallest at the same time (rotifer, $0.2 \mu \mathrm{g}$; copepod, $5 \mu \mathrm{g}$ and cladoceran, $8 \mu \mathrm{g}$ ). Mean copepod weight was significantly larger $(9 \mu \mathrm{g})$ in the 1960s-1970s than in the following decades. This was caused by the presence of the large-sized E. gracilis and also by C.kolensis in plankton in that period. The analysed ratio $\mathrm{N}_{\mathrm{Cal}} / \mathrm{N}_{\mathrm{Cycl}}$ demonstrated the gradual extinction of calanoid copepods ( $\mathrm{P}<0.0001$, Fig. 5); the ratio $\mathrm{N}_{\text {Crust }} / \mathrm{N}_{\text {Rot }}$ showed the higher role of rotifers in the zooplankton community in the 1980s-1990s and the ratio $\mathrm{N}_{\text {Largeclad }} / \mathrm{N}_{\text {Clad }}(\%)$ showed a decreasing trend in the abundance of large-sized cladocerans $(\mathrm{P}<0.0001$, Fig. 6).

Tab. 3. Comparison of the abundances of total zooplankton, zooplankton groups and characteristic species for the studied decades (mean and 0.9 quantile in parentheses for the growing season, and P-values of the Kruskall-Wallis Dunn's test).

\begin{tabular}{|c|c|c|c|c|c|c|}
\hline Abundance (ind $\mathrm{L}^{-1}$ ) & $1960 \mathrm{~s}$ & $1970 \mathrm{~s}$ & $1980 \mathrm{~s}$ & $1990 \mathrm{~s}$ & $2000 \mathrm{~s}$ & P-value \\
\hline Zooplankton & 642 (1719) & 487(946) & $\underline{886(2034)}$ & 1041(2644) & $455(804)$ & $<0.0001$ \\
\hline Rotifera & $527(1583)$ & $347(1280)$ & $745(1905)$ & $878(2540)$ & $319(644)$ & $<0.0001$ \\
\hline Cladocera & $67(200)$ & $75(203)$ & 87 (194) & $89(283)$ & 49 (157) & $<0.0001$ \\
\hline Copepoda & $48(108)$ & 64 (139) & $64(150)$ & $60(133)$ & $86(160)$ & 0.01 \\
\hline Anuraeopsis fissa & 0 & 2 & *254(1300) & $\underline{156(761)}$ & $28(203)$ & $<0.0001$ \\
\hline Conochilus unicornis & $\underline{86(176)}$ & $19(105)$ & $16(74)$ & 2 & 0 & $<0.0001$ \\
\hline Filinia longiseta & $\overline{12(60)}$ & $10(32)$ & $12(62)$ & $\underline{2.5(15)}$ & 0 & $<0.0001$ \\
\hline Kellicottia longispina & $\underline{67(244)}$ & $4(48)$ & $1(6)$ & $1(11)$ & 0 & $<0.0001$ \\
\hline Keratella cochlearis & $* \overrightarrow{258(1300)}$ & *216(1034) & $162(1095)$ & $291(2135)$ & ${ }^{*} 109(604)$ & 0.01 \\
\hline Ploesoma hudsoni & $\underline{0.3(2)}$ & 0 & 0 & 0 & 0 & $<0.0001$ \\
\hline Polyarthra luminosa & $* 41(220)$ & $22(88)$ & ${ }^{*} \underline{164(756)}$ & *199(724) & *83(360) & $<0.0001$ \\
\hline Trichocerca rousseleti & $6(63)$ & $16(87)$ & $218171)$ & $64(343)$ & $16(95)$ & 0.08 \\
\hline Bosmina berolinensis & $1.3(2)$ & $0.2(2)$ & 0 & 0 & 0 & 0.08 \\
\hline Bosmina c.coregoni & $\underline{21(96)}$ & $9(25)$ & $6.5(48)$ & $0.9(9)$ & $0.9(3)$ & $<0.0001$ \\
\hline Bosmina longirostris & $\overline{1.46)}$ & $6(32)$ & $6(25)$ & $6(18)$ & $5(30)$ & 0.2 \\
\hline Chydorus sphaericus & *31 (90) & *53 (226) & *53 (190) & *72 (261) & $38(152)$ & 0.001 \\
\hline Daphnia cucullata & $\underline{9(27)}$ & $6(21)$ & $3(34)$ & $7(32)$ & $\underline{2(10)}$ & $<0.0001$ \\
\hline gen.Mesocyclops & $* 43$ & $* 58$ & 64 & *53 & ${ }^{*} 86$ & NS \\
\hline Cyclops kolensis & $3(8)$ & $1(3)$ & 0 & 0 & 0 & $<0.0001$ \\
\hline Eudiaptomus gracilis & $4(9)$ & $\underline{3(9)}$ & 0 & 0 & 0 & $<0.0001$ \\
\hline
\end{tabular}

"Species dominating ( $\geq 20 \%$ of the zooplankton abundance) in more than $20 \%$ samples of the decade; underlined values indicate significantly distinctive decades; NS, not significant.

Tab. 4. The results of the indicator species analysis. Indices of association between a species and decades are calculated after De Cáceres and Legendre (2009) (P-values of permutation test).

\begin{tabular}{|c|c|c|c|c|c|c|}
\hline Species & $1960 \mathrm{~s}$ & $1970 \mathrm{~s}$ & $1980 \mathrm{~s}$ & $1990 \mathrm{~s}$ & $2000 \mathrm{~s}$ & P-value \\
\hline Bosmina c.coregoni & ${ }^{*} 0.54$ & 0.16 & 0.23 & 0.05 & 0.02 & 0.001 \\
\hline Daphnia cucullata & ${ }^{*} 0.34$ & ${ }^{*} 0.22$ & 0.11 & ${ }^{*} 0.28$ & 0.07 & 0.001 \\
\hline Cyclops kolensis & 0.24 & ${ }^{*} 0.76$ & 0 & 0 & 0 & 0.001 \\
\hline Eudiaptomus gracilis & ${ }^{*} 0.56$ & 0.43 & 0 & 0 & 0 & 0.001 \\
\hline Gen. Mesocyclops & 0.14 & 0.19 & 0.21 & 0.18 & ${ }^{*} 0.28$ & 0.002 \\
\hline Anuraeopsis fissa & 0 & 0.01 & ${ }^{*} 0.57$ & ${ }^{*} 0.36$ & 0.06 & 0.005 \\
\hline Ploesoma hudsoni & ${ }^{*} 0.91$ & 0.07 & 0.010 & 0 & 0 & 0.001 \\
\hline Conochilus unicornis & ${ }^{*} 0.7$ & 0.16 & 0.13 & 0.01 & 0 & 0.001 \\
\hline Filinia longiseta & ${ }^{*} 0.32$ & 0.28 & 0.32 & 0.07 & 0.01 & 0.002 \\
\hline Kellicottia longispina & ${ }^{*} 0.80$ & 0.16 & 0.010 & 0.02 & 0 & 0.001 \\
\hline Trichocerca rousseleti & 0.05 & 0.13 & 0.17 & ${ }^{*} 0.52$ & 0.13 & 0.006 \\
\hline
\end{tabular}

"Indicator species for decade. 


\section{DISCUSSION}

Rakocevic-Nedovic and Hollert (2005) have emphasized that long-term monitoring is needed for a better estimation of the state and conditions of water bodies. The data of nutrients for the 1960s and the 1970s reveal an evident increase in the nitrate and phosphate concentrations in the 1970s, which was the first sign of the further eutrophication of Lake Võrtsjärv. Beginning from the 1980s nutrient concentrations increased significantly due to extensive animal husbandry and the excessive use of fertilizers in land cultivation. In the same period the external load to the lake was high ( $\mathrm{N}$ load $3621 \mathrm{t} \mathrm{y}^{-1}$, P load $94 \mathrm{t} \mathrm{y}^{-1}$ ) but it decreased significantly in 1992-2004 ( $\mathrm{N}$ load $1762 \mathrm{t} \mathrm{y}^{-1}$, $\mathrm{P}$ load $61 \mathrm{t} \mathrm{y}^{-1}$ ) owing to the decline in agricultural activity and a better purification of wastewater from settlements (Nõges et al., 2007).

We distinguished between several zooplankton measures and studied their ability to follow changes in the

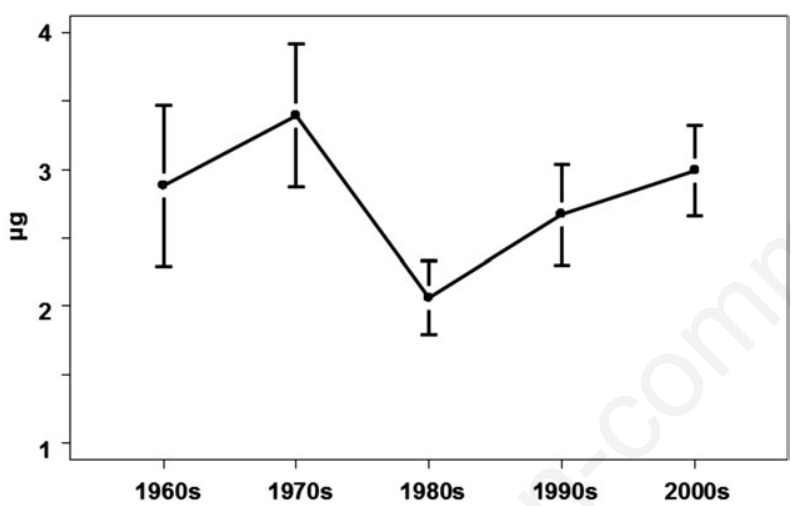

Fig. 4. Mean zooplankter weight (mean with $95 \%$ confidence limits) for the growing season.

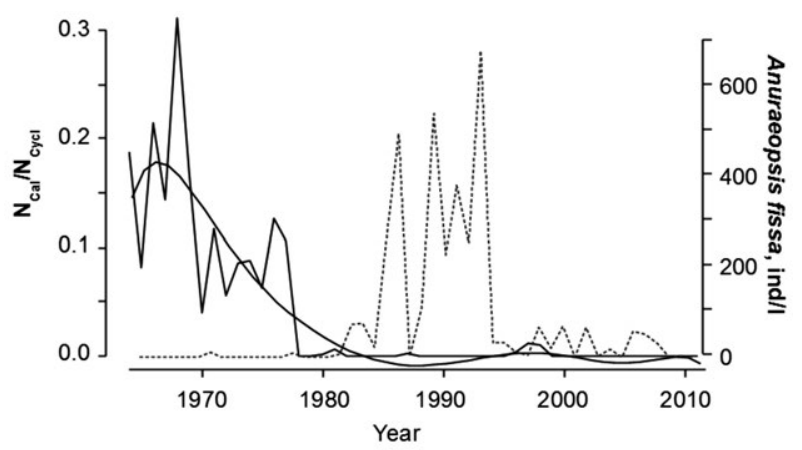

Fig. 5. Annual summer means of the abundance of Anuraeopsis fissa (dotted line) and the dynamics of the ratio of calanoid copepods to cyclopoid copepods $\left(\mathrm{N}_{\mathrm{Cal}} / \mathrm{N}_{\mathrm{Cycl}}\right)$. trophic state of Lake Võrtsjärv. Zooplankton was indicative at all levels from the 1960s: i) somewhat indicative at the level of total abundance; ii) moderately indicative at the level of groups (Cladocera, Copepoda, Rotifera); iii) highly indicative at the level of species. Several studies (Pejler, 1983; Karabin, 1985; Andronikova, 1996; Jeppesen et al., 2000) have demonstrated significant relationships between nutrient concentrations and water taxon diversity. Andronikova (1996) has found that in oligotrophic lakes the Shannon-Wiener diversity index for the zooplankton community is 2.6-4.0; in mesotrophic lakes, 2.1-2.5; in eutrophic lakes, 1.0-2.0; according to Chen et al. (2012), it was 1-2 in mesotrophic waters and 2-3 in oligotrophic waters for rotifers. In Lake Võrtsjärv, the Shannon-Wiener diversity index for zooplankton community remained between 1.0-2.0. As a result of eutrophication, large-sized zooplankters, feeding on small algae, disappeared gradually from Lake Vorrtsjärv due to the

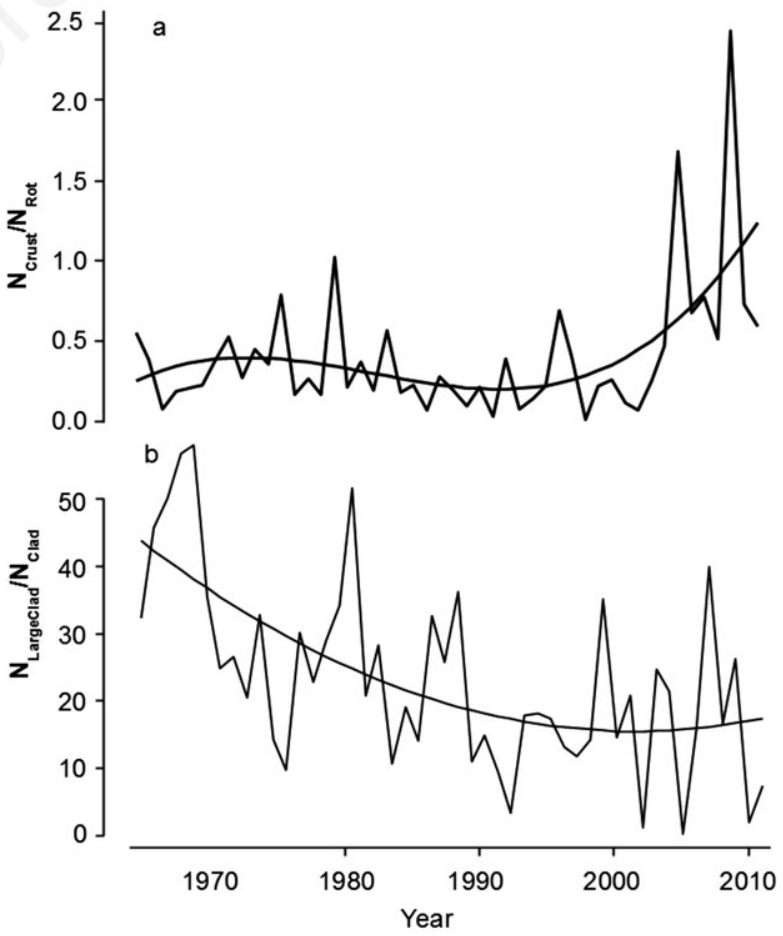

Fig. 6. a) Dynamics of the ratio of crustacean abundance to rotifer abundance $\left(\mathrm{N}_{\text {Crust }} / \mathrm{N}_{\text {Rot }}\right)$, means of the annual growing season with a significant trend. b) Dynamics of the ratio of large $(>10$ $\mu \mathrm{g}$ ) cladoceran abundance to total cladoceran group abundance $\left(\mathrm{N}_{\text {LargeClad }} / \mathrm{N}_{\text {Clad, }} \%\right)$, means of the annual growing season with a significant trend. 
scarcity of food, and plankton became dominated by small zooplankters (rotifers and small cladocerans) feeding on bacteria and detritus. Also the ratio of the abundance of large-sized $(>10 \mu \mathrm{g})$ cladocerans to the abundance of the whole cladoceran group $\left(\mathrm{N}_{\text {Largeclad }} / \mathrm{N}_{\text {Clad }}\right)$ followed flexibly changes in the cladoceran community as well as in the lake's trophic state from the 1960s up to the 2000s. It demonstrates that replacement of large cladocerans by small forms is an essential phenomenon in the eutrophication process, and that $\mathrm{N}_{\text {LargeClad }} \mathrm{N}_{\text {Clad }}$ is a valuable indicator of the eutrophication process (Moss et al., 2003).

In Lake Võrtsjärv, zooplankton abundance is quite high, while its biomass is low, which is characteristic of highly eutrophic water bodies with small weight of zooplankton individuals. Mean zooplankter weight decreases with increasing trophy as small zooplankters begin to dominate in the zooplankton community (Gulati, 1984; Andronikova, 1996; Jeppesen et al., 2000; Haberman and Laugaste, 2003, Ejsmont-Karabin, 2012). In the strongly eutrophic Lake Võrtsjärv, zooplankter weight was on average $2.7 \mu \mathrm{g}$; in the moderately eutrophic Lake Peipsi it was $5 \mu \mathrm{g}$ in 1965-1966 and $4 \mu \mathrm{g}$ in 1997-2006 (Haberman, 2001). Andronikova (1996) found that the zooplankter is 3.3 times as light in eutrophic as in oligotrophic waters. At this point, we have to underline that fishes, preferring larger food objects, may also have a great role in the formation of mean zooplankter weight (Schönberg, 1958; Nielsen et al., 2000). Nevertheless, mean zooplankter weight can be used as an indicator for evaluating the trophy of a water body and its ecosystem, and particularly, for constant long-term monitoring of water bodies (Jeppesen et al., 2011). The rising trophy of a water body is accompanied by the increasing numbers of rotifers (Gulati, 1984; Manca et al., 1992; Hofmann and Höfle, 1993; Oltra et al., 2001). The zooplankton abundance of the eutrophic Lake Võrtsjärv was also mainly $(65 \%)$ built by rotifers. Several zooplankton researchers (Chen et al., 2012; Gunn et al., 2012; Ejsmont-Karabin, 2012) have stated that rotifers have a potential as bioindicators of the lake's trophic state; they have a short life cycle and may respond concurrently to environmental changes. Karabin et al. (1997) have reminded, that the eutrophication process and fish predation influence crustacean communities, with the exclusion of big individuals, in a similar way. Changes in community structure, indicating an increase in the lake's trophy, may actually reflect an impact of fish on the zooplankton community. No such evident impact was observed in the case of rotifers as they are a rather accidental food of fish. Of course, we have to take into account that cladocerans (especially large Daphnia species) can reduce the densities of rotifer assemblages through competition for food and interference (Gilbert, 1988; Fradkin, 1995). Also, the predation of copepods (Brandl, 2005) and the large-bodied rotifer Asplanchna (Guiset, 1977), as well as the suppression by toxic strains of cyanobacteria (Gilbert, 1994) may reduce the abundance of rotifers. As the genus Daphnia is represented in Lake Võrtsjärv by only one species, $D$. cucullata, and its role has never been important, its competition for food and interference has not been significant. The abundance of rotifers in Lake Võrtsjärv in the growing season fluctuated between 164 ind $\mathrm{L}^{-1}$ (in October) and 1168 ind $\mathrm{L}^{-1}$ (in May), the average being 560 ind $\mathrm{L}^{-1}$. According to Karabin (1985), a lake is meso- or meso-oligotrophic at a rotifer abundance of $<400$ ind $\mathrm{L}^{-1}$, eutrophic at 400-2000 ind $\mathrm{L}^{-1}$ and hypertrophic at $>2000$ ind $\mathrm{L}^{-1}$. According May and O'Hare (2005), rotifer abundance may even be a more sensitive indicator of the trophic state and of changes in the trophic state, compared with species composition. In Lake Mikołajskie (Poland) maximum rotifer abundance increased from 2000 ind $\mathrm{L}^{-1}$ in 1963-1964 to 8000 ind $\mathrm{L}^{-1}$ in 1989-1990 as the lake became increasingly more eutrophic (Ejsmont-Karabin and Hillbricht-Ilkowska, 1994). In Lake Võrtsjärv the share of rotifers in total zooplankton abundance was the largest in the 1980s, which demonstrates the effect of nutrient increase on rotifers. The higher role of rotifers is also supported by the ratio of crustacean abundance to rotifer abundance $\left(\mathrm{N}_{\text {Crust }} / \mathrm{N}_{\mathrm{Rot}}\right)$, which was the lowest in the 1980s. The sharp decline in the abundance of rotifers in the 2000s is not easily explicable. It may be caused both by a minor decrease in the trophy of the lake and, most likely, by an increase in the abundance of predatory cyclopoid copepods (gen. Mesocyclops). In Lake Vorrtsjärv the dominating rotifers throughout the study period were A. fissa, K. cochlearis, P. luminosa and T. rousseleti. K. cochlearis made up 29\% of rotifer abundance and $20 \%$ of total zooplankton abundance; the corresponding data for P. luminosa, were 30\% and $18 \%$. A. fissa, a well-known indicator of eutrophy (Hakkari, 1972; Pejler, 1983; Gulati, 1990; Barrabin, 2000), was not found in the 1960s but reached its maximum in the $1980 \mathrm{~s}$, accounting for $27 \%$ of rotifer abundance and $20 \%$ of zooplankton abundance. According to Pejler (1962) and Duggan et al. (2001), Keratella. tecta (Gosse) is one of the best indicators of eutrophy. Recently (in the 2000s) the abundance of $K$. tecta in Lake Vorrtsjärv amounted to 700 ind $\mathrm{L}^{-1}$ and it made up $82 \%$ of the abundance of rotifers. Both $K$. longispina and C. unicornis are known as species favouring the lower trophic state (Hofmann and Höfle, 1993; May and O'Hare, 2005; Gunn et al., 2012. Both species were quite numerous in the 1960s, after which they followed changes in the trophic state and disappeared from plankton by the 2000s. Also P. hudsoni, a species of lower trophy (Baião and Boavida, 2005), has disappeared. Filinia longiseta (Ehrenberg) has been considered a species of eutrophic waters (Hakkari, 1972; Pejler, 1983; Duggan et al., 2001; Ejsmont-Karabin, 2012), but in the eutrophic Lake Võrtsjärv its abundance showed 
a declining trend during the study period. Asplancha herricki de Guerne, a rotifer preferring oligotrophic water bodies (Hakkari, 1972; Pejler, 1983; Andronikova, 1996), was found only in the 1920 (Mühlen and Schneider, 1920) but not later.

The abundance of cladocerans (Cladocera) is modest in Lake Võrtsjärv; however, owing to their comparatively large mean individual weight $(9 \mu \mathrm{g})$, they dominate (46\%) in zooplankton biomass (Haberman and Virro, 2004). The indicator species of eutrophic waters $C$. sphaericus (Godeanu, 1978; Vijverberg and Boersma, 1997; Marcé et al., 2005) is the most important cladoceran in this lake, dominating $(61 \%$ of abundance in the cladoceran group and $20 \%$ in whole zooplankton abundance) in zooplankton throughout the growing season. B. longirostris, also an indicator of eutrophy (Godeanu, 1978; Jeppesen et al., 1999; Caramujo and Boavida, 2000; Gąsiorowski and Szeroczyńska, 2004), has always been present in Lake Võrtsjärv but was never a dominant in the 1920s (Mühlen and Schneider, 1920) and in the 1960s. Beginning from the 1970s, cladoceran abundance (more often biomass) was dominated by $B$. longirostris in spring (May) and in autumn (October). In the 1990s, B. longirostris and $B$. coregoni changed their roles:the abundance of the former increased while that of the latter decreased. In the 1960s B. coregoni was present in $80 \%$ of the samples with a maximum abundance of 94 ind $\mathrm{L}^{-1}$, constituting up to $73 \%$ of cladoceran abundance, while beginning from the early 1990s it practically disappeared from zooplankton. In Lake Søbygaard (Denmark) too, a fossil record revealed a shift from $B$. coregoni to $B$. longirostris (Davidson et al., 2011). Also in upper Lake Constance, the succession from $B$. longispina to $B$. longirostris was attributed to eutrophication (Hofmann, 1998). Nevertheless, one cannot deny the possible impact of fishes on this change. In Lake Võrtsjärv, Bosmina berolinensis Imhof always occurred with low abundance, and it disappeared from plankton in the 1980s. The species of oligomesotrophic waters, Bythotrephes longimanus Leydig (Hakkari, 1972) disappeared from the lake already in the early 1960s (Haberman, 1998). The copepod (Copepoda) group in Lake Võrtsjärv consisted generally of juveniles (nauplii and copepodites) of the Mesocyclops leuckarti Claus and Thermocyclops oithonoides Sars. Nauplii made up $47 \%$ and copepodites $45 \%$ of total copepod abundance. Domination of zooplankters with short generation time and juvenile forms in zooplankton is typical of eutrophic waters. Adults of both M. leuckarti and T. oithonoides accounted for about $2 \%$ of the abundance of the copepod group. Scarce occurrence of adult copepods (particularly large egg-carrying females) indicates the pressure of fish. In a recent study (Ginter et al., 2011) on the stomach content of pikeperch fry, the Ivlev selectivity index revealed high positive selection for adult $M$. leuckarti. The calanoid copepod E. gracilis is a species of lower trophy (Chapman, 1969; Gulati, 1984; Shumka, 2001; May and O'Hare, 2005; Væærvågen and Nilssen, 2010) and was numerous in the 1950s (Shönberg, 1958) and even in the 1960s. It started to decrease beginning from the 1970s and virtually disappeared from the plankton of Lake Võrtsjärv in the 1980s. The decrease in the average density of $E$.

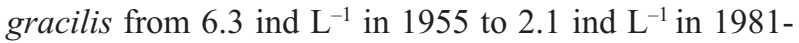
1982 in Loosrecht lakes was also caused by an increase in the trophic state (Gulati, 1984). As E. gracilis is the only calanoid copepod in Lake Võrtsjärv, the ratio of calanoid abundance to cyclopoid copepod abundance $\left(\mathrm{N}_{\text {Cal }} / \mathrm{N}_{\text {Cycl }}\right)$ reflects adequately the dynamics of the abundance of E.gracilis as well as that of the genera Mesocyclops and Thermocyclops. Recently, in the 2000s, the abundance of cyclopoid copepods increased significantly. The ratio $\mathrm{N}_{\text {Cal }} / \mathrm{N}_{\text {Cycl }}$ frequently declines with increasing eutrophication (Gannon and Stemberger, 1978; Gulati, 1984; Caramujo and Boavida, 2000). Gannon and Stemberger (1978) have found that $\mathrm{N}_{\text {Cal }} / \mathrm{N}_{\text {Cycl }}$ is a good indicator of trophic conditions, which is also supported by our results.

\section{CONCLUSIONS}

Basing on the results of our study (1964-2011) and taking into account relevant data from numerous zooplankton studies, we can conclude that the zooplankton measures deserving to be used as indicators in the monitoring of Lake Võrtsjärv (and other similar eutrophic water bodies) could be the following: i) indicatory species of eutrophic waters (A. fissa, K. tecta, T. rousseleti, C. sphaericus, B. longirostris); ii) indicatory species of oligo-mesotrophic waters (C. unicornis, $K$. longispina, $P$. hudsoni, $B$. berolinensis, E.gracilis); iii) number and diversity of species; iv) mean zooplankter weight, mean cladoceran weight, mean rotifer weight and mean copepod weight; v) rotifer abundance; vi) the share (\%) of rotifers in total zooplankton abundance; vii) the ratio of abundance of large cladocerans to abundance of all cladocerans $\left(\mathrm{N}_{\text {Largeclad }} /\right.$ $\mathrm{N}_{\text {Clad }}$; viii) the ratio of calanoid copepod abundance to cyclopoid copepod abundance $\left(\mathrm{N}_{\mathrm{Cal}} \mathrm{N}_{\mathrm{Cyc}}\right)$; ix) the ratio of crustacean abundance to rotifer abundance $\left(\mathrm{N}_{\text {Crust }} / \mathrm{N}_{\text {Rot }}\right)$. We believe that several zooplankton measures have a high value as invaluable tools in assessment of the trophic state and water quality of water bodies. We wholly share the opinion of other zooplankton researchers (Moss, 2007; Caroni and Irvine, 2010; Davidson et al., 2011; Jeppesen et al., 2011; Ejsmont-Karabin, 2012) that in the European Union zooplankton as a central element of biological quality be definitely included in the Water Frame Directive.

\section{ACKNOWLEDGMENTS}

The research was supported through targeted financing by the Estonian Ministry of Education and Research 
(project SF 0170006s08). In this study hydrobiological collections of the Centre for Limnology and data from the Estonian State Monitoring Programme were used. We are indebted to Mrs. Ester Jaigma for revising the English text of this paper. The contribution of the referees is highly appreciated.

\section{REFERENCES}

Agasild H, Zingel P, Tõnno I, Haberman J, Nõges T, 2007. Contribution of different zooplankton groups in grazing on phytoplankton in shallow eutrophic Lake Võrtsjärv (Estonia). Hydrobiologia 584:167-177.

Andronikova I, 1996. [Structural and functional organization of zooplankton in large ecosystems of different trophic level]. [Book in Russian]. Nauka: 189 pp.

Baião C, Boavida MJ, 2005. Rotifers of Portuguese reservoirs in river Tejo catchment:Relations with trophic state. Limnetica 24:103-114.

Balushkina EV, Vinberg, GG, 1979. [Relation between body mass and length in planktonic animals], p. 169-175. In: G.G. Vinberg (ed.), [Fundamentals of water ecosystem research]. [Book in Russian]. Nauka.

Barrabin JM, 2000. The rotifers of Spanish Reservoirs:ecological, systematical and zoogeographical remarks. Limnetica 19:91-167.

Blank K, Laugaste R, Haberman J, 2010. Temporal and spatial variation in the zooplankton:phytoplankton biomass ratio in a large shallow lake. Est. J. Ecol. 59:99-115.

Brandl J, 2005. Freshwater copepods and rotifers: predators and their prey. Hydrobiologia 546:475-489.

Caramujo MJ, Boavida MJ, 2000. The crustacean communities of river Tagus Reservoirs. Zooplankton structure as reservoir trophic state indicator. Limnetica 18:37-56.

Caroni R, Irvine K, 2010. The potential of zooplankton communities for ecological assessment of lakes: redundant concept or political oversight? Biol. Environ. Proc. R. Ir. Acad. 110B:35-53.

Carpenter KE, Johanson JM, Buchanan C, 2006. An index of biotic integrity based on summer polyhaline zooplankton community of the Chesapeake Bay. Mar. Environ. Res. 62:165-180.

Carlson RE, 1977. A trophic state index for lakes. Limnol. Oceanogr. 22:361-369.

Chapman A, 1969. The bionomics of Diaptomus gracilis Sars (Copepoda; Calanoida) in Loch Lomond, Scotland. J. Anim. Ecol. 38/2:257-283.

Chen L, Liu Q, Peng Z, Hu Z, Xue Z, Wang W, 2012. Rotifer community structure and assessment of water quality in Yangcheng Lake. Chin. J. Oceanol. Limnol. 30:47-58.

Davidson T, Bennion AH, Jeppesen E, Clarke GH, Sayer C, Morley D, Odgaard BV, Rasmussen P, Rawcliffe R, Salgado J, Simpson GL, Amsinck SL, 2011. The role of cladocerans in tracking long-term change in shallow lake trophic status. Hydrobiologia 676:299-315.

de Cáceres M, Legendre P, 2009. Associations between species and groups of sites:indices and statistical inference. Ecology 90:3566-3574.

del Arco AI, Ferreira V, Graça MAS, 2012. The performance of biological indicators in assessing the ecological state of streams with varying catchment urbanisation levels in Coimbra, Portugal. Limnetica 31:141-154.

Downing JA, Plante C, Lalonde S, 1990. Fish production correlated with primary productivity, not the morfoedaphic index. Can. J. Fish. Aquat. Sci. 47:1929-1936.

Duggan IC, Green JD and Shiel RJ, 2001. Distribution of rotifers in North Island, New Zealand, and their potential use as bioindicators of lake trophic state. Hydrobiologia 446/447:155-164.

Ejsmont-Karabin J, 2012. The usefulness of zooplankton as lake ecosystem indicators:rotifer trophic index. Pol. J. Ecol. 60:339-350.

Ejsmont-Karabin J, Hillbricht-Ilkowska A, 1994. Illustration of the eutrophication process:comparison of rotifers from Mikołajskie Lake in the years 1989-1990 and 1963-1964. Pol. Arch. Hydrobiol. 41:477-487.

Fradkin SC, 1995. Effect of interference and exploitative competition from large-bodied cladocerans on rotifer community structure. Hydrobiologia 313/314:387-393.

Gannon JE, Stemberger RS, 1978. Zooplankton (especially crustacean and rotifers) as indicators of water quality. T. Am. Micros. Soc. 97:16-35.

Gąsiorowski M, Szeroczyńska K, 2004. Abrupt changes in Bosmina (Cladocera, Crustacea) assemblages during the history of the Ostrowite Lake (northern Poland). Hydrobiologia 526:137-144.

Gilbert JJ, 1988. Susceptibilities of ten rotifer species to interference from Daphnia pulex. Ecology 69:1826-1838.

Gilbert JJ, 1994. Susceptibilities of planktonic rotifers to a toxic strain of Anabaena flos-aquae. Limnol. Oceanogr. 39:1286-1297.

Ginter K, Kangur K, Kangur A, Kangur P, Haldna, M, 2011. Diet patterns and ontogenetic diet shift of pikeperch, Sander lucioperca (L.) prey in lakes Peipsi and Võrtsjärv (Estonia). Hydrobiologia 660:79-91.

Godeanu SP, 1978. Specificity of the zooplankton in several lakes from northern Germany with different degree of eutrophication. Verh. Int. Verein Limnol. 20:963-968.

Guiset A, 1977. Stomach contents in Asplanchna and Ploesoma. Arch. Hydrobiol. 8:126-129.

Gulati RD, 1984. Zooplankton and its grazing as measures of trophy in the Loosdrecht lakes. Verh. Int. Verein Limnol. 22:863-867.

Gulati RD, 1990. Structural and grazing responses of zooplankton community to biomanipulation of some Dutch water bodies. Hydrobiologia 200/201:99-118.

Gunn ID, O’Hare MT, Maitland PS, May L, 2012. Long-term trends in Loch Leven invertebrate communities. Hydrobiologia 681:59-72.

Haberman J, 1998. Zooplankton of Lake Võrtsjärv. Limnologica 28:49-65.

Haberman J, 2001. Zooplankton, p. 50-68. In: E. Pihu and J. Haberman (eds.), Lake Peipsi. Flora and Fauna. Sulemees Publ.

Haberman J, Laugaste R, 2003. On characteristics reflecting the trophic state of large and shallow Estonian lakes (L. Peipsi, L. Võrtsjärv). Hydrobiologia 506/509:737-744.

Haberman J, Laugaste R, Nõges T, 2007. The role of cladocerans reflecting the trophic status of two large and shallow Estonian lakes. Hydrobiologia 584:157-166. 
Haberman J, Virro T, 2004. Zooplankton, p. 233-251. In: J. Haberman, E. Pihu and A. Raukas (eds.), Lake Võrtsjärv. Estonian Encyclopedia Publ.

Hakkari L, 1972. Zooplankton species as indicators of environment. Aqua Fenn. 1972:46-54.

Hofmann W, 1998. The response of Bosmina (Eubosmina) to eutrophication of Upper Lake Constance: the subfossil record. Arch. Hydrobiol. 53:275-283.

Hofmann W, Höfle G, 1993. Rotifer population dynamics in response to increased bacterial biomass and nutrients:a mesocosm eksperiment. Hydrobiologia 255:171-175.

Ivanova MB, 1985. [Productivity of planktonic crustaceans in freshwater water bodies]. [Book in Russian]. Nauka: 220 pp.

Jeppesen E, Jensen JP, Søndergaard M, Lauridsen T, 1999. Trophic dynamics in turbid and cleanwater lakes with special emphasis on the role of zooplankton for water clarity. Hydrobiologia 408/409:217-231.

Jeppesen E, Jensen P, Søndergaard M, Lauridsen T, Landkildehus F, 2000. Trophic structure, species richness biodiversity in Danish lakes: changes along phosphorus gradient. Freshwater Biol. 45:201-218.

Jeppesen E, Nõges P, Davidson TA, Haberman J, Nõges T, Blank K, Lauridsen T, Søndergaard M, Sayer C, Laugaste R, Johansson LS, Bjerring R, Amsinck SL, 2011. Zooplankton as indicators in lakes: a scientific-based plea for including zooplankton in the ecological quality assessment of lakes according to the European Water Framework Directive (WFD). Hydrobiologia 676:279-297.

Kane DD, Gordon SI, Munavar M, Charlton MN, Culver DA, 2009. The Planktonic index of biotic integrity (P-1131): an approach for assessing lake ecosystem health. Ecol. Indic. 9:1234-1247.

Karabin A, 1985. Pelagic zooplankton (Rotatoria+Crustacea) variation in the process of lake eutrophication. I. Structural and quantitative features. Ekol. Polska 33:567-616.

Karabin A, Ejsmont-Karabin J, Kornatowska R, 1997. Eutrophication processes in a shallow, macrophyte-dominated lake - factors influencing zooplankton structure and density in Lake Łuknajno (Poland). Hydrobiologia 342/343:401-409.

Kisand V, Nõges T, 1998. Seasonal dynamics of bacterio- and phytoplankton in large and shallow eutrophic Lake Võrtsjärv, Estonia. Int. Rev. Hydrobiol. 83:205-216.

Manca M, Colderoni AA, Mosello R, 1992. Limnological research in Lago Maggiore: studies on hydrochemistry and plankton. Mem. Ist. Ital. Idrobiol. 50:171-200.

Marcé R, Comerma M, Garcia JC, Gomé J, Armengol J, 2005. The zooplankton community in a small, hypertrophic mediterranean reservoir (Foix reservoir, NE Spain). Limnetica 24:275-294.

May L, O'Hare M, 2005. Changes in rotifer species composition and abundance along a trophic gradient in Loch Lomond, Scotland, UK. Hydrobiologia 546:397-404.

Moss B, 2007. Shallow lakes, the water framework directive and life. What should it all be about? Hydrobiologia 584:381-394.

Moss B, Stephen D, Alvarez C Becares E, Van De Bund W, Collings SE, Van Donk E, De Eyto E, Feldmann T, Fernández-Aláez C, Fernández-Aláez M, Franken RJM, GarcíaCriado F, Gross EM, Gyllström M, Hansson LA, Irvine K, Järvalt A, Jensen JP, Jeppesen E, Kairesalo T, Kornijów R, Krause T, Künnap H, Laas A, Lill E, Lorens B, Luup H, Mir- acle MR, Nõges P, Nõges T, Nykänen M, Ott I, Peczula W, Peeters ETHM, Phillips G, Romo S, Russell V, Salujõe J, Scheffer M, Siewertsen K, Smal H, Tesch C, Timm H, Tuvikene L, Tonno I, Virro T, Vicente E, Wilson D, 2003. The determination of ecological status in shallow lakes - a tested system (ECOFRAME) for implementation of the European Water Framework Directive. Aquat. Conser. 13:507-549.

Mühlen M, Schneider G, 1920. [Die Fauna], p. 14-22. In: [Der See Wirzjerw in Livland. Biologie und Fischerei]. [Book in German]. C. Mattiesen.

Nielsen DL, Hillmann TJ, Smith FJ, Shiel J, 2000. The influence of planktivorous fish on zooplankton assemblages in experimental billabongs. Hydrobiologia 434:1-9.

Nõges T, Nõges P, Haberman J, Kisand V, Kangur K, Kangur A, Järvalt A, 1998. Food web structure in shallow eutrophic Lake Võrtsjärv (Estonia). Limnologica 28:115-128.

Nõges T, Agasild H, Haberman J, Kangur A, Kangur K, Kangur P, Timm H, Zingel P, Nõges P, 2004. Food Webs in Lake Võrtsjärv, p. 335-345. In: J. Haberman, E. Pihu and A. Raukas (eds.), Lake Võrtsjärv. Estonian Encyclopedia Publ.

Nõges T, Järvet A, Kisand A, Laugaste R, Loigu E, Skakalski B, Nõges B, 2007. Reaction of large and shallow lakes Peipsi and Võrtsjärv to the changes of nutrient loading. Hydrobiologia 584:253-264.

Nõges T, Laugaste R, Nõges P, Tõnno I, 2008. Critical N:P ratio for cyanobacteria and $\mathrm{N}_{2}$-fixing species in the large shallow temperate lakes Peipsi and Võrtsjärv, North-East Europe. Hydrobiologia 599:77-86.

Nõges T, Tuvikene L, Nõges P, 2010. Contemporary trends of temperature, nutrient loading, and water quality in large lakes Peipsi and Võrtsjärv, Estonia. Aquat. Ecosyst. Health 13:143-153.

Oksanen J, Blanchet FG, Kindt R, Legendre P, Minchin PR, O'Hara RB, Simpson GL, Solymos P, Stevens MHH, Wagner H, 2011. Vegan: community ecology, R package version 2.0-2.

Oltra RM, Alfonso T, Sahuquillo M, Miracle MR, 2001. Increase of rotifer diversity after sewage diversion in the hypertrophic lagoon, Albufera of Valencia, Spain. Hydrobiologia 446/447:213-220.

Pejler B, 1962. On the variation of the rotifer Keratella cochlearis (Gosse). Zool. Bidr. Upps. 35:1-17.

Pejler B, 1983. Zooplankton indicators of trophy and their food. Hydrobiologia 101:111-114.

R Development Core Team, 2011. R: a language and environment for statistical computing. R Foundation for Statistical Computing, Vienna, Austria.

Rakocevic-Nedovic J, Hollert H, 2005. Phytoplankton community and chlorophyll a as trophic state indices of Lake Skadar (Montenegro, Balkan). Environ. Sci. Pollut. Res. 12:146-152.

Rodionov SN, 2004. A sequential algorithm for testing climate regime shifts. Geophys. Res. Lett. 31:L09204.

Ruttner-Kolisko A, 1977. Suggestions for biomass calculation of planktonic rotifers. Arch. Hydrobiol. Beih. Ergebn. Limnol. 8:71-76.

Schönberg N, 1958. [Angaben über die Futterbasis und Ernährung der planktonfressenden Fische des Sees Wõrtsjärv].[Article in German]. Hydrobiol. Res. 1:191-201.

Shumka S, 2001. Feeding relations of Eudiaptomus gracilis (SARS) and influence on some parameters of their life cycle 
in Lake Ohrid. Verh. Int. Verein Limnol. 27:3708-3711. Studenikina EI, Cherepahina MM, 1969. [Mean weight of basic zooplankton forms of the Azov Sea]. [Article in Russian]. Hydrobiol. Journal [Gidrobiol. Zhurnal] 5:89-91.

Virro T, 1989. [The comparison of sampling methods of planktonic rotifers (Rotatoria) on the example of Lake Peipsi]. [Article in Russian]. Proc. Eston. Acad. Sci. Biol. 38: 119.122.

Vijverberg J, Boersma M, 1997. Long-term dynamics of smallbodied and large-bodied cladocerans during the eutrophicar- tion of a shallow reservoir, with special attention for Chydorus sphaericus. Hydrobiologia 360:233-242.

Vollenweider RA, Kerekes J, 1982. Eutrophication of Waters. Monitoring, Assessment and Control. OECD. Cooperative programme on monitoring of inland waters (Eutrophication control). Environment Directorate. OECD: 154 pp.

Vǣrvågen SB, Nilssen JP, 2010. Life histories and seasonal dynamics of common boreal pelagic copepods (Crustacea, Copepoda) in habiting an oligotrophic Fennoscandian lake. J. Limnol. 69:311-332. 